\title{
Inactivation and Disinfection of Poliovirus Type 1 on Nonporous Carriers
}

\author{
Cory Chiossone ${ }^{1}$, Semhar Fanuel ${ }^{1}$, Lukyn M Gedge ${ }^{2}$, Raymond W Nims ${ }^{3}$, Donna B Suchmann ${ }^{1}$ and S Steve Zhou ${ }^{1 *}$ \\ ${ }^{1}$ Microbac Laboratories, USA
}

${ }^{2}$ Microbide Limited, Ireland

${ }^{3} R M C$ Pharmaceutical Solutions, USA

Submission: June 01, 2018; Published: July 02, 2018

*Corresponding author: S Steve Zhou, Microbac Laboratories, Inc., 105 Carpenter Drive, Sterling, VA 20164, USA, Tel: +1 7039250100;

Email: steve.zhou@microbac.com

\begin{abstract}
The inactivation of poliovirus type 1 (PV-1) deposited on glass carriers in the presence of low vs. high organic loads was investigated using two micellized aldehyde-based disinfectants and sodium hypochlorite. Inactivation at $21{ }^{\circ} \mathrm{C}$ of PV-1 deposited on glass carriers in the presence of low organic load was rapid (within 1 minute) and complete $\left(\geq 3 \log _{10}\right)$ for Microbide-S $(100,000 \mathrm{ppm})$, Microbide-G $(30,000 \mathrm{ppm})$ and sodium hypochlorite $(30,000 \mathrm{ppm})$. Disinfectant concentrations less than 10,000ppm resulted in incomplete inactivation of PV-1 at up to 5 minutes contact time at this low level of organic load. In the presence of high organic load, the three disinfectants also displayed rapid (within 1 minute) and complete ( $\geq 3-4 \log _{10}$ ) inactivation of PV-1 when applied at concentrations $>10,000 \mathrm{ppm}$. The efficacies of the three disinfectants for inactivating PV-1 on glass carriers were therefore found to be similar at one-minute contact time, regardless of the presence of low vs. high organic load, although the time kinetics of inactivation deviated rapidly from linearity in the case of PV-1 in the presence of high organic load. This is thought to reflect binding of active agents to the organic load or protection of virus by the organic load. The impact of this can be mitigated by applying a high concentration of disinfectant $(>10,000 \mathrm{ppm})$. The results indicate that Microbide-S and Microbide-G display efficacies comparable to sodium hypochlorite for inactivation of PV-1 deposited on non-porous surfaces in the presence of low or high organic load and can be used as successful anti-viral disinfectants.
\end{abstract}

Keywords: Sodium hypochlorite; Disinfectant; Microbide-S; Microbide-G; Non-enveloped virus; Organic load; Poliovirus type 1

\section{Introduction}

Poliovirus is a clinically relevant enterovirus from the Picornaviridae family of non-enveloped viruses. Prior to the introduction of inactivated and attenuated poliovirus vaccines in the 1950's, the virus caused considerable global panic from 1890 onward [1]. Although the majority of poliovirus infections result in an abortive flu-like prodrome or are asymptomatic, in $\sim 5 \%$ of infections, a meningitic phase with varying degrees of flaccid paralytic outcome follow the prodrome [2]. Enteroviruses, including polioviruses, are viruses which are transmitted through the oral/fecal route. As implied by this, oral secretions and fecal excretions from infected individuals are capable of infecting new hosts via the gastrointestinal tract of a noninfected individual. Interruption of the cycle of infection and reinfection of enteroviruses may be facilitated by disinfection interventions that are capable of inactivating the virus. In order to be of practical use, such disinfectants should cause a significant reduction in pathogen load on environmental surfaces (fomites) under ambient conditions following a relatively short contact time.
Non-enveloped viruses are not susceptible to detergents or lipid solvents, and other types of chemical disinfectants must be used. For preparation of the inactivated (Salk) poliomyelitis vaccines of the 1950's, poliovirus was inactivated with formaldehyde. Incomplete inactivation of vaccine poliovirus leading to iatrogenic poliomyelitis in $\sim 200$ individuals was attributed to the presence of viral aggregates or of an excess of foreign protein in the inactivation solutions [1]. In particular, the presence of cell debris in the vaccine pools due to inadequate purification prevented suitable exposure of the viral particles to formaldehyde, resulting in incomplete inactivation $[3,4]$. Protection, by viral aggregation or by sequestering in a protein matrix, of viruses from exposure to disinfectant active agents is suggested by this unfortunate case of inactivation failure. The presence of organic load at the time of deposition of a virus onto a fomite is therefore an important factor that must be considered when assessing viral inactivation efficacy.

Efficacy testing of active agents intended for disinfection of surfaces is best performed in carrier studies, rather than 
in solution studies [5-9]. In addition, the presence of organic load at the time of deposition of the virus can be investigated to realistically model the contamination of a surface by a virus suspended in blood or other organic matrices (urine, sputum, etc.) [8-10]. In the present study, we have evaluated the efficacy of three disinfectants against PV-1 deposited on glass carriers

Table 1: Properties and mechanisms of action of the products evaluated.

\begin{tabular}{|c|c|c|c|c|c|}
\hline Product & Agent & Active & Class & pH of Undiluted Formulation & Inactivation Mechanism \\
\hline Microbide $®-S$ & Microbide-S & Succindialdehyde & Micellized aldehyde & 6.7 & $\begin{array}{c}\text { Cross-linking of proteins and } \\
\text { nucleic acids [11] }\end{array}$ \\
\hline Microbide $®-G$ & Microbide-G & Glutaraldehyde & Micellized aldehyde & 7.3 & $\begin{array}{c}\text { Cross-linking of proteins and } \\
\text { nucleic acids [11] }\end{array}$ \\
\hline Clorox $®$ & Bleach & Sodium hypochlorite & Oxidizing agent & 11.9 & Oxidation of thiol groups [11] \\
\hline
\end{tabular}

Materials and Methods

\section{Reagents}

Sodium hypochlorite solutions were prepared by dilution of Clorox $\AA$ bleach at 30,000ppm (3.0\%) active. Microbide-G and Microbide-S solutions at 30,000ppm (3.0\%) active and $100,000 \mathrm{ppm}(10.0 \%)$ active, respectively, were provided by Microbide Limited (Dublin, Ireland).

\section{Viruses}

Poliovirus type 1 (PV-1), strain Chat (ATCC VR-1562), was selected as it is a commonly employed strain available from the American Type Culture Collection (ATCC; Manassas, VA). The virus was propagated in rhesus monkey kidney (LLC-MK2) cells (ATCC CCL-7.1) at $36 \pm 2{ }^{\circ} \mathrm{C}$ with $5 \pm 3 \% \mathrm{CO}_{2}$ in Roswell Park Memorial Institute (RPMI) 1640 medium supplemented with 5\% newborn calf serum (NCS; Thermo Fisher Scientific; Waltham, MA). The flasks were frozen at $-80{ }^{\circ} \mathrm{C}$ and then thawed at ambient temperature for three cycles. The conditioned medium was collected and clarified at $2,000 \mathrm{rpm}$ for $15 \mathrm{~min}$, and the resulting supernatant was purified with an ultra-centrifuge. The viral pellet was re-suspended in a serum-free medium and aliquoted and stored at $-80{ }^{\circ} \mathrm{C}$ until use. The certified titer of the PV-1 stock used in these studies was $8.81 \log _{10}$ tissue culture infectious dose ${ }_{50}$ per $\mathrm{mL}\left(\mathrm{TCID}_{50} / \mathrm{mL}\right)$ in African green monkey kidney (MA-104) cells obtained from Charles River Laboratories (Malvern, PA).

\section{Surface inactivation studies}

Solutions of the disinfectants were prepared by dilution, as required, in $400 \pm 2.9 \% \mathrm{ppm} \mathrm{AOAC}$ hard water. The organic load of the virus inocula consisted of 5\% fetal bovine serum (FBS) from ThermoFisher Scientific (low organic) or 90\% Defibrinated Sheep's Blood from Cocalico Biologicals, Inc.; Stevens, PA (high organic). Microbide-S was tested at concentrations ranging from 2,000 to $100,000 \mathrm{ppm}$. Microbide-G and sodium hypochlorite were tested at concentrations ranging from 600 to $30,000 \mathrm{ppm}$. For each treatment, $0.4-\mathrm{mL}$ aliquots of virus in the presence of the organic load were spread onto a $4 \mathrm{in}^{2}$ area of a sterile glass Petri dish and were allowed to dry at ambient temperature (21 ${ }^{\circ} \mathrm{C}$ ) for $21-35 \mathrm{~min}$. in the presence of a high ( $90 \%$ sheep blood) or low (5\% fetal bovine serum) organic load. The surface inactivation efficacies of two proprietary micellized aldehyde products (Table 1) from Microbide Limited (Microbide $\AA-G$ and Microbide $®-S$ ) were compared with that of solutions of sodium hypochlorite.
The experimental design for the inactivation studies followed the general procedure outlined in the ASTM E1053-11 standard [12]. For each disinfectant, $2.0 \mathrm{~mL}$ of test solution were applied directly to the virus film deposited onto a glass carrier. The solutions were allowed to completely cover the virus film for the entirety of the 15-s, 30-s, 1-min, 2-min, 5-min, or 10-min contact times at $21{ }^{\circ} \mathrm{C}$. Following the contact times, $2.0 \mathrm{~mL}$ of neutralizer (Minimum Essential Medium (MEM) + 10\% FBS + $1 \%$ glycine for neutralizing Microbide-G and Microbide-S; MEM $+10 \% \mathrm{FBS}+0.5 \% \mathrm{Na}_{2} \mathrm{~S}_{2} \mathrm{O}_{3}$ for neutralizing sodium hypochlorite) were added. After neutralization, the mixtures were scraped from the surface of the glass carriers with a cell scraper. An 0.8-mL volume of each sample was transferred to a Sephacryl column and subjected to centrifugation at $1,000 \mathrm{rpm}$ for $3 \mathrm{~min}$. Each contact time was evaluated in a single replicate $(n=1)$ for each disinfectant.

To determine remaining infectious PV-1 virus titers following collection from carriers, the post-neutralization samples (PNS) were serially diluted and selected dilutions added $(0.05 \mathrm{~mL})$ to 96-well plates containing MA-104 cells. The plates were incubated at $36 \pm 2{ }^{\circ} \mathrm{C}$ with $5 \pm 3 \% \mathrm{CO}_{2}$ for 6 -9 days. Following incubation, the MA-104 and monolayers were examined microscopically for the presence of viral cytopathic effects (CPE) or for evidence of cytotoxicity due to the disinfectants. The CPE results were used to calculate the virus titer of the challenge virus stock or post-neutralization samples in units of $\mathrm{TCID}_{50} / \mathrm{mL}$ using the Spearman-Kärber method [13].

\section{Inactivation study controls}

Plate recovery control (PRC): This control was performed as a single replicate as done in the disinfectant test runs, with $2.0 \mathrm{~mL}$ of dilution medium added to the dried virus instead of disinfectant.

Neutralizer effectiveness/Viral interference controls (NE/VI): This control was performed for each type of disinfectant as a single replicate in a manner identical to the test runs, except that $0.4 \mathrm{~mL}$ of diluent was dried onto the carriers instead of virus. At the completion of the contact times, the control carriers were subjected to neutralization procedures identical to those 
used for the test carriers. This control was then divided into two portions, one used as the Cytotoxicity Control and one used as the NE/VI. An aliquot of the NE/VI PNS was subjected to serial 10 -fold dilution. Following dilution, $0.1 \mathrm{~mL}$ of stock PV-1 virus containing approximately $1,000-5,000 \mathrm{TCID}_{50}$ was added to each dilution and held for the longest contact time prior to inoculation of the MA-104 cells.

Cytotoxicity control (CT): This control was performed for each type of disinfectant as a single replicate. This control was performed in a manner analogous to the NE/VI runs, except that no virus was added to the samples after serial dilution prior to the inoculation of MA-104 cells.

Cell viability control (CVC): This control was performed as a single replicate. Eight wells of MA-104 cells received only diluent to demonstrate the viability of the cells throughout the assay period.

Virus stock titer control: This control was performed as a single replicate. An aliquot of PV-1 stock (i.e., inoculum) was serially diluted and inoculated onto MA-104 cells to demonstrate that the titer of the challenge PV-1 virus stock used in the inactivation study was approximately the same as the certified titer for the PV-1 stock.

\section{Results \\ Inactivation efficacy and contact time-dependence in
the presence of low organic load}

The efficacies of Microbide-S, Microbide-G, and sodium hypochlorite for inactivating PV-1 deposited on glass carriers in the presence of low organic load (5\% FBS) were evaluated at ambient temperature $\left(21{ }^{\circ} \mathrm{C}\right)$. The results have been displayed in Figure 1. The deposition of virus in the presence of low organic load enabled the determination of the "bestcase" surface inactivation efficacies for these disinfectants. As displayed in Figure 1A-1C, time- and concentration-dependent inactivation of PV-1 was observed for each of the three active agents. The time-dependence for inactivation was nearly firstorder for Microbide-S at 2,000ppm (0.62 $\log _{10}$ reduction in titer per minute; $\left.\mathrm{R}^{2}=0.95\right)$, Microbide- $\mathrm{G}$ at $3,000 \mathrm{ppm}\left(1.22 \log _{10}\right.$ reduction in titer per minute; $\mathrm{R}^{2}=0.91$ ), and sodium hypochlorite at 3,000ppm (1.10 $\log _{10}$ reduction in titer per minute; $\left.R^{2}=0.97\right)$. Microbide-S at $100,000 \mathrm{ppm}$ and Microbide-G at $30,000 \mathrm{ppm}$ caused complete inactivation $\left(\geq 3.38 \log _{10}\right.$ ) of PV-1 within 1 to 15 -seconds contact time. Sodium hypochlorite at 30,000ppm caused complete inactivation $\left(\geq 4.38 \log _{10}\right)$ of PV-1 within a 1-minute contact time.

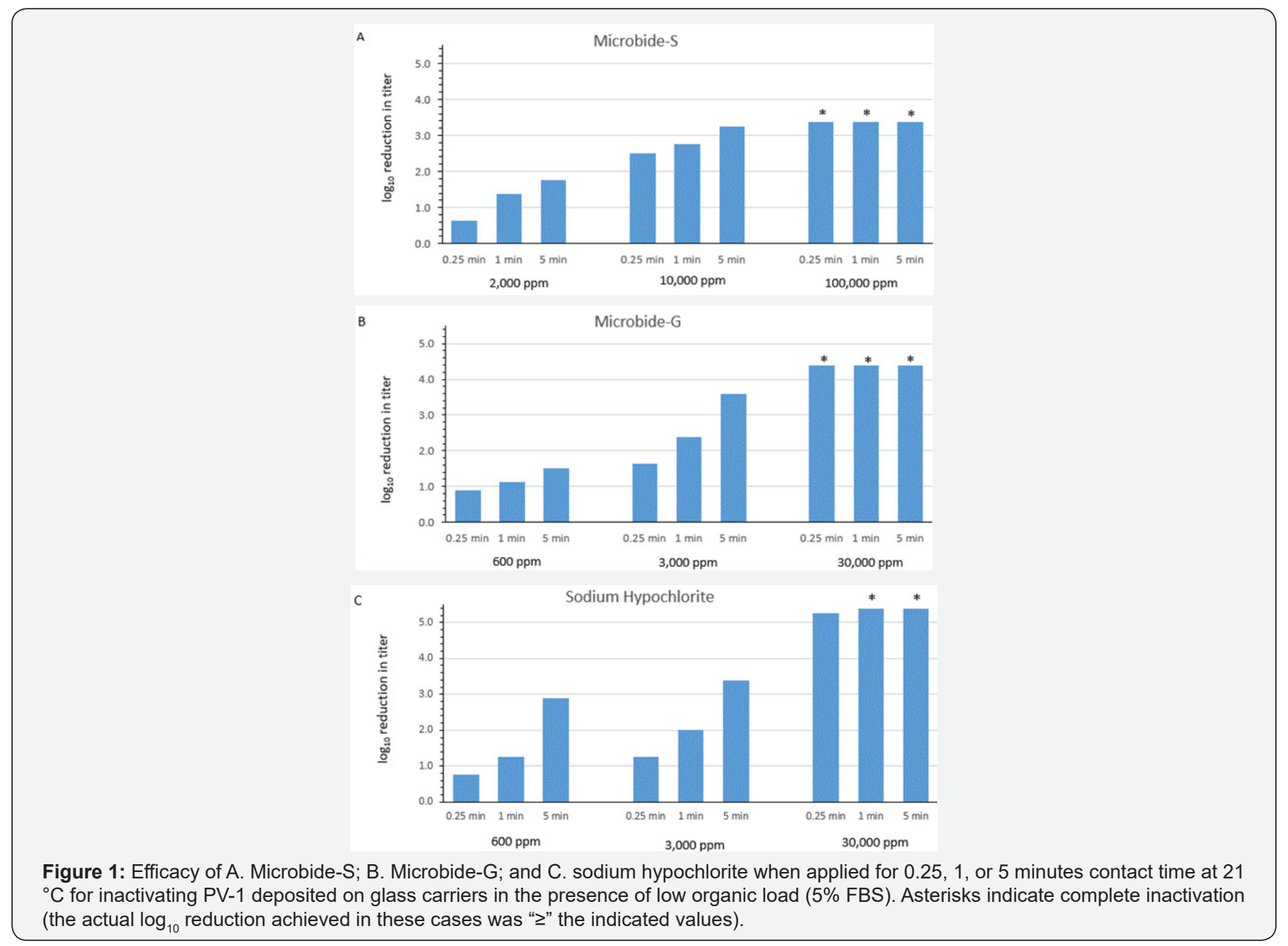




\section{Inactivation efficacy and contact time-dependence in the presence of high organic load}

A high organic load ( $90 \%$ sheep blood) deposited along with virus on glass carriers was expected to reduce the efficacy of, or alter the time kinetics for, PV-1 inactivation by the three disinfectants. Under these conditions, the efficacies of Microbide-S, Microbide-G, and sodium hypochlorite for inactivating PV-1 were dependent on contact time (Figure 2A2C) and disinfectant concentration (Figure 3), although neither of these relationships was linear. The PV-1 inactivation vs. time kinetics for each of the disinfectants displayed rapid deviation from linearity within the initial few minutes of contact time at ambient temperature (Figure 2). Complete inactivation of $\mathrm{PV}-1$ required 10 minutes of contact time for Microbide-S at $2,000 \mathrm{ppm}$ and Microbide-G at 600 or $3,000 \mathrm{ppm}$. Complete inactivation of PV-1 was not achieved by 600 or 3,000ppm sodium hypochlorite. Complete inactivation of PV-1 occurred within a 1-minute contact time for Microbide-S $(10,000$ and 30,000ppm), Microbide-G (15,000ppm), and sodium hypochlorite $(30,000 \mathrm{ppm})$. The concentration/inactivation response relationships for each disinfectant were non-linear at the 15-second contact time (Figure 3), and within this very short time frame, complete $\left(\geq 3.38 \log _{10}\right)$ inactivation of PV- 1 was achieved by Microbide-S (30,000ppm) only.

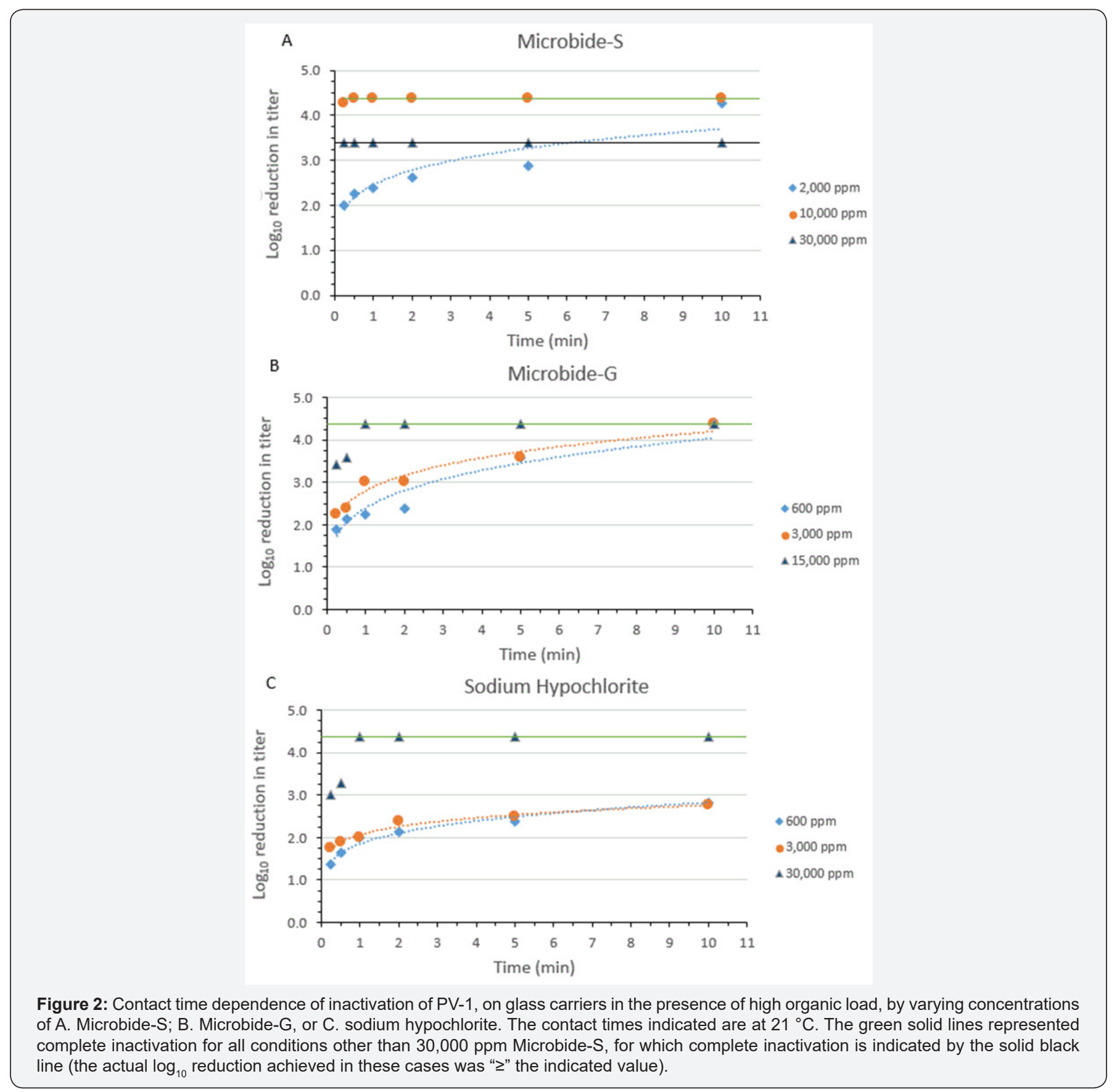




\section{Advances in Biotechnology \& Microbiology}

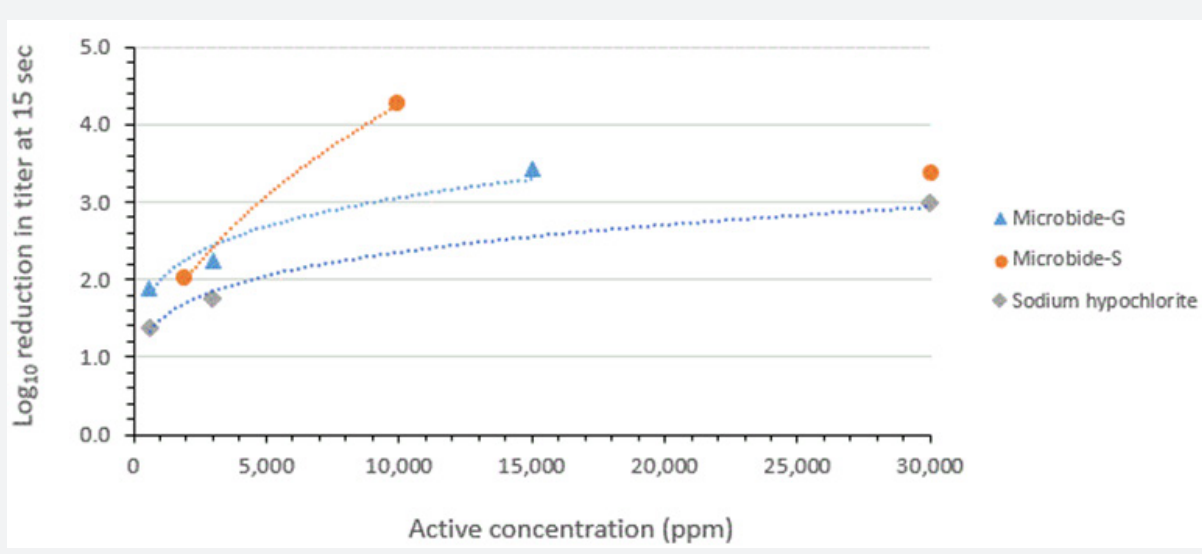

Figure 3: Microbide-S, Microbide-G, and sodium hypochlorite concentration dependence for inactivation of PV-1 deposited on glass carriers in the presence of high organic load ( $90 \%$ sheep's blood). A contact time of 15 seconds at $21^{\circ} \mathrm{C}$ was evaluated in this plot. The value for 30,000 ppm Microbide-S represented complete inactivation (the actual $\log _{10}$ reduction achieved was " $\geq$ " the indicated value).

\section{Discussion}

Poliovirus, being a small, non-enveloped virus, represents a challenge for many of the chemical inactivants, especially detergents and solvents that are effective against viruses with lipid envelopes. For this reason, poliovirus has commonly been used as a model virus for studying the inactivation efficacy of disinfectants, sanitizers and sterilants. For instance, The Health Canada guidance documents "Safety and Efficacy Requirements for Hard Surface Disinfectant Drugs" [14] and "Human-Use Antiseptic Drugs" [15] each specify PV-1 as one of the model viruses that should be used to determine an acceptable level of inactivation efficacy. A European standard applicable to efficacy testing of chemical disinfectants and antiseptics for human use (EN14476:2013+A1:2015) [16] mandates the use of PV-1 as a model virus for determining the inactivation efficacy of hygienic handrubs and handwashes, instrument disinfectants, and surface disinfectants. In addition, the Centers for Disease Control and Prevention (CDC) "Interim Guidance for Environmental Infection Control in Hospitals for Ebola Virus" [17] states that poliovirus is one of several non-enveloped viruses that may be used as model viruses for determining acceptable inactivation efficacy of disinfectants in hospitals treating patients under investigation for, or known to have, Ebola disease or other hemorrhagic diseases. The ability of chemical disinfectants to meet efficacy requirements for inactivating PV-1 helps to assure that these disinfectants will also provide adequate efficacy for enveloped viruses, such as Ebola virus.

Aldehydes such as glutaraldehyde are commonly used for inactivation of entero viruses, including poliovirus, on medical instruments such as endoscopes that might be damaged by alternative chemical or physical approaches [18,19]. The mechanism of inactivation is generally considered to be crosslinking of viral proteins, especially VP1 and VP3 [18] and nucleic acids. In solution inactivation studies performed in the presence of low organic load, the inactivation of poliovirus by alkaline glutaraldehyde solutions has been characterized as first-order with respect to contact time. For instance, Bailly et al. [19] determined the rate of inactivation of PV-1 (Sabin strain) by alkaline glutaraldehyde in solution inactivation studies as 0.1 $\log _{10}$ per minute for a $1,000 \mathrm{ppm}$ solution. These investigators also observed a linear concentration dependence such that by extrapolation, 2,000ppm and 3,000ppm solutions would be expected to cause $0.2 \log _{10}$ and $0.3 \log _{10}$ inactivation per minute, respectively). These inactivation rates are considerably lower than the $1.22 \log _{10}$ inactivation per minute observed for $3,000 \mathrm{ppm}$ Microbide-G in our study. The difference may reflect a greater efficacy for inactivation of PV-1 on surfaces compared to inactivation in solution. Alternatively, the difference may be due to the specific micellization of glutaraldehyde in Microbide-G. The rate of inactivation of PV-1 deposited on glass carriers in the presence of low organic load was similar for the 3,000ppm concentration of sodium hypochlorite $\left(1.1 \log _{10} /\right.$ minute $)$ to that for 3,000ppm Microbide-G.

Singh et al. [20] conducted carrier inactivation studies with Seneca Valley virus (Senecavirus A; another picornavirus) in the absence of an organic load. They found that 2,500ppm sodium hypochlorite at $25^{\circ} \mathrm{C}$ inactivated 1.5 to $3.4 \log _{10}$ within 1 minute, depending on the non-porous surface type, and 3.5 to $\geq 4.0 \log _{10}$ at 10 minutes. The surface for which the values at the low end of the range were obtained was stainless steel, while aluminum and plastic resulted in values at the higher end of the range. Mbithi et al. [21] observed greater than $4 \log _{10}$ inactivation of the picornavirus hepatitis A virus deposited on stainless steel disks in the presence of clarified and filtered $10 \%$ fecal organic load by a one-minute contact time with $20,000 \mathrm{ppm}$ alkaline glutaraldehyde or 5,500ppm sodium hypochlorite.

The impact of high organic load on viral inactivation efficacy has been described previously for Zika virus and West Nile virus [8] (members of the flavivirus family), and for bovine viral diarrhea virus and hepatitis A virus [22] (members of the flavivirus and picornavirus families, respectively). In the studies of Zika virus inactivation, a 90\% sheep blood matrix present at 
the time of virus deposition onto carriers resulted in protection of the virus from the inactivating effects of sodium hypochlorite. In the present study, for PV-1 deposited on glass carriers in the presence of high organic load ( $90 \%$ sheep blood), inactivation by the three active agents was not first-order with respect to time. For each disinfectant, rapid (i.e., within one minute of contact time) deviation from linearity of the inactivation vs. time plots was observed for each concentration applied.

This behavior of Microbide-G, Microbide-S, and sodium hypochlorite for inactivation of virus deposited on glass carriers in the presence of high organic load has also been observed previously [9] for inactivation of porcine parvovirus. This was attributed to partitioning of the active agent into the organic load. That aldehydes and sodium hypochlorite are susceptible to partitioning into organic material has been emphasized previously by Harvey [23] and Weber et al. [24]. The latter authors determined that the presence of $80 \%$ blood in solution inactivation studies of PV-1 caused reduction in efficacy and alteration in time kinetics of inactivation by $5,000 \mathrm{ppm}$ sodium hypochlorite [24].

As postulated previously [9], the decrease in incremental disinfectant activity for incremental contact time intervals (Figure 2) in the presence of high organic load may reflect binding (reversible or irreversible, or both) of the active agents to the organic material. In addition, the virus may be sequestered into the organic material affording protection from the active agent [25], and the virus/organic interaction may be reversible or irreversible. This is consistent with the fact that failures in obtaining complete inactivation of poliovirus in live vaccines in the 1950 s were mitigated by implementing filtration steps prior to and following the formaldehyde inactivation step [4].

Each of the three disinfectants evaluated in this study displayed rapid (within 1 minute) and complete (3-4 $\log _{10}$ ) inactivation of PV-1 deposited onto a glass carrier in the presence of a high organic load when applied at concentrations $>10,000 \mathrm{ppm}(1 \%)$ at $21^{\circ} \mathrm{C}$. When considering the use of highly efficacious cleaning products against persistent viruses such as Ebola, it is important to think of these products in the context of their usage. Wider biological and practical considerations are often ignored in surface inactivation studies because of the focus on efficacy. The high $\mathrm{pH}$ of sodium hypochlorite is repeatedly cited as damaging to human skin [26], the environment [27], and surfaces intended to be disinfected $[18,19]$. In comparison, Microbide-S and Microbide-G have a near neutral $\mathrm{pH}$ (Table 1 ), meaning that the inactivation efficacy in the case of these products is not associated with the undesired caustic impact of sodium hypochlorite.

\section{Conclusion}

Surface inactivation at $21{ }^{\circ} \mathrm{C}$ of PV-1 deposited on glass carriers in the presence of low organic load was rapid (within 1 minute) and complete ( $\geq 3 \log _{10}$ ) for Microbide-S $(100,000 \mathrm{ppm})$, and Microbide-G and sodium hypochlorite $(30,000 \mathrm{ppm})$. Disinfectant concentrations less than $10,000 \mathrm{ppm} \mathrm{(1 \% )} \mathrm{resulted}$ in incomplete inactivation of PV-1 at up to 5 minutes contact time. Each of the three disinfectants displayed rapid (within 1 minute) and complete ( $\geq 3-4 \log _{10}$ ) inactivation of PV-1 deposited onto glass carriers in the presence of high organic load when applied at concentrations $>10,000 \mathrm{ppm}$ at $21^{\circ} \mathrm{C}$. Although the efficacies of the three disinfectants for inactivating PV-1 on glass carriers were similar at one-minute contact time, regardless of the presence of low vs. high organic load, the time kinetics of inactivation deviated rapidly from linearity in the case of PV-1 in the presence of high organic load. This is thought to reflect binding of active agents to the organic load or protection of virus by the organic load. The impact of this can be mitigated by applying a high concentration of disinfectant $(>10,000 \mathrm{ppm})$. Considering the efficacy of the products is similar, the nearneutrality of the Microbide-S and Microbide-G products means they are superior in terms of real-world applications/usage for/ against fomites.

\section{Conflict of Interest}

Funding for the inactivation studies described herein, and for the authoring of this manuscript was provided by Microbide Limited (Dublin, Ireland).

\section{Acknowledgements}

This research conforms to the Welcome Trust's global initiative of open access to research data.

\section{References}

1. Baicus A (2012) History of polio vaccination. World J Virol 1: 108-114.

2. Howard RS (2014) Poliomyelitis. In: Hilton-Jones D, Turner MR (Eds.), Oxford Textbook of Neuromuscular Disorders, Oxford University Press, UK, pp. 51-60.

3. Sanders B, Koldijk M, Schuitemaker H (2015) Inactivated viral vaccines. In: Nunnally BK, Turula VE, Sitrin RD (Eds.), Vaccine Analysis: Strategies, Principles, and Control, Springer, Germany, pp. 45-80.

4. Gard S (1957) Inactivation of poliovirus by formaldehyde. Bull World Health Org 17(6): 979-989.

5. Sattar SA, Springthorpe VS, Adegbunrin O, Zafer AA, Busa M (2003) A disc-based quantitative carrier test method to assess the virucidal activity of chemical germicides. J Virol Meth 112: 3-12.

6. Eterpi M, McDonnell G, Thomas V (2010) Virucidal activity of disinfectants against parvoviruses and reference viruses. Appl Biosaf 15: $165-171$.

7. Rabenau HF, Steinmann J, Rapp I, Schwebke I, Eggers M (2014) Evaluation of a virucidal quantitative carrier test for surface disinfectants. PLoS One 9: s86128.

8. Wilde C, Chen Z, Kapes T, Chiossone C, Lukula S, et al. (2016) Inactivation and disinfection of Zika virus on a nonporous surface. J Microb Biochem Technol 8: 422-427.

9. Lukula S, Chiossone C, Fanuel S, Suchmann DB, Nims RW, et al. (2017) Inactivation and disinfection of porcine parvovirus on a non-porous surface. J Microb Biochem Technol 9: 232-236. 
10. Thraenhart O, Jursch C (2005) Virucidal testing of surface-disinfectants with the quantitative carrier test - Contribution to the influence of blood on virus inactivation, Hygiene + Medizin 30(1): 12-19.

11. McDonnell G, Russell AD (1999) Antiseptics and disinfectants; Activity, action, and resistance. Clin Microbiol Rev 12: 147- 227.

12. ASTM E1053-11 (2011) Standard test method to assess virucidal activity of chemicals intended for disinfection of inanimate, nonporous environmental surfaces. ASTM International, USA.

13. Finney DJ (1978) Statistical Methods in Biological Assay. ( $\left.3^{\text {rd }} e d n\right)$, McMillan Co, Inc., New York, USA, pp. 394-401.

14. Health Canada (2018) Guidance Document - Disinfectant Drugs. https://www.canada.ca/en/health-canada/services/drugs-healthproducts/drug-products/applications-submissions/guidancedocuments/disinfectants/safety-efficacy-requirements-hard-surfacedisinfectant-drugs.html

15. Health Canada (2009) Guidance Document - Human-Use antiseptic Drugs. https://www.canada.ca/en/health-canada/services/drugshealth-products/drug-products/applications-submissions/guidancedocuments/human-use-antiseptic-drugs.html

16. BSI (2013) BS EN 14476:2013+A1:2015 Chemical disinfectants and antiseptics. Quantitative suspension test for the evaluation of virucidal activity in the medical area. Test method and requirements (Phase 2/Step 1). https://shop.bsigroup.com/ ProductDetail/?pid=000000000030318301

17. Centers for Disease Control and Prevention (2018) Interim Guidance for Environmental Infection Control in Hospitals for Ebola Virus. https://www.cdc.gov/vhf/ebola/healthcare-us/cleaning/hospitals. html

18. Chambon M, Bailly JL, Peigue-Lafeuille H (1992) Activity of glutaraldehyde at low concentrations against capsid proteins of poliovirus type 1 and echovirus type 25. Appl Environ Microbiol 58(11): 3517-3521.
19. Bailly JL, Chambon M, Peigue-Lafeuille $H$, Laveran $H$, de Champs $C$, et al. (1991) Activity of glutaraldehyde at low concentrations $(<2 \%)$ against poliovirus and its relevance to gastrointestinal endoscope disinfection procedures. Appl Environ Microbiol 57(4): 1156-1160.

20. Singh A, Mor SK, Aboubakr H, Vannucci F, Patnayak DP, et al. (2017) Efficacy of three disinfectants against Senecavirus A on five surfaces and at two temperatures. J Swine Health Prod 25: 64-68.

21. Mbithi JN, Springthorpe VS, Sattar SA (1990) Chemical disinfection of hepatitis A virus on environmental surfaces. Appl Environ Microbiol 56: 3601-3604.

22. Terpstra FG, van den Blink AE, Bos LM, Boots AGC, Brinkhuis FHM, et al. (2007) Resistance of surface-dried virus to common disinfection procedures. J Hosp Infect 66(4): 332-338.

23. Harvey SC (1980) Antiseptics and disinfectants: fungicides; ectoparasiticides. In: Gilman AG, Goodman LS, Gilman A (Eds.), The Pharmacological Basis of Therapeutics, $\left(6^{\text {th }}\right.$ edn $)$, Macmillan Publishing Co., UK.

24. Weber DJ, Barbee SL, Sobsey MD, Rutala WA (1999) The effect of blood on the antiviral activity of sodium hypochlorite, a phenolic, and a quaternary ammonium compound. Infect Control Hosp Epidemiol 20: 821-827.

25. Hejkal TW, Wellings FM, LaRock PA, Lewis AL (1979) Survival of poliovirus within organic solids during chlorination. Appl Environ Microbiol 38: 114-118.

26. HostynekJJ, Wilhelm KP, Cua A, Maibach HI (1990) Irritation factors of sodium hypochlorite solutions in human skin. Contact Der 23: 316324 .

27. Emmanuel E, Keck G, Blanchard JM, Vermande P, Perrodin Y (2004) Toxicological effects of disinfections using sodium hypochlorite on aquatic organisms and its contribution to AOX formation in hospital wastewater. Environ Int 30(7): 891-900.

\section{Your next submission with Juniper Publishers will reach you the below assets}

- Quality Editorial service

- Swift Peer Review

- Reprints availability

- E-prints Service

- Manuscript Podcast for convenient understanding

- Global attainment for your research

- Manuscript accessibility in different formats

( Pdf, E-pub, Full Text, Audio)

- Unceasing customer service

Track the below URL for one-step submission https://juniperpublishers.com/online-submission.php 